\title{
The Effect of Guided Inquiry Learning and Cognitive Style on Science Learning Achievement
}

\author{
I Gede Margunayasa
}

Universitas Pendidikan Ganesha, Indonesia, pakgun_pgsd@yahoo.com

\section{Nyoman Dantes}

Prof., Universitas Pendidikan Ganesha, Indonesia, dantes_nyoman@yahoo.com

\section{A.A.I.N Marhaeni}

Prof., Universitas Pendidikan Ganesha, Indonesia,ngurah_marhaeni@yahoo.com

\section{Wayan Suastra}

Prof., Universitas Pendidikan Ganesha, Indonesia, i_wayansuastra@ yahoo.com

This research was aimed to analyze the effect of interaction between guided inquiry learning and cognitive style on students' science learning achievement. This study was a quasi-experiment with a $2 \times 2$ factorial design. The study was done with the fifth grade students in Singaraja City. The sample was selected using multi stage random sampling and 4 elementary schools were selected for the experimental group $(n=132)$ and another 4 for the control group $(n=107)$. The experimental group used guided inquiry learning and the control group used conventional teaching model. The study used science learning achievement test and MFFT cognitive style test as the instruments for collecting the data. The result of hypothesis testing showed that: 1) there is a significant difference in science learning achievement between those who learned with guided inquiry learning model and those who learned with conventional teaching; and 2) there is a significant effect of interaction between guided inquiry learning model and cognitive style on students' science learning achievement. Guided inquiry learning is more optimal in increasing students' learning achievement if it is implemented to students with reflective cognitive style than to those with impulsive cognitive style.

Keywords: cognitive style, guided inquiry, science learning achievement, teaching, learning

\section{INTRODUCTION}

Nowadays the world of education faces a lot of problems, both internal and external. Susanto states that one of the problems encountered by the world of education is the

Citation: Margunayasa, I G., Dantes, N., Marhaeni, A.A.I.N., \& Suastra, I W. (2019). The Effect of Guided Inquiry Learning and Cognitive Style on Science Learning Achievement. International Journal of Instruction, 12(1), 737-750. https://doi.org/10.29333/iji.2019.12147a 
problem of a weak implementation of the teaching and learning process by teachers at schools (Susanto, 2013). The result of Nur's study showed that the use of learning resources at elementary schools in Bireun regency in terms of the use learning resource variations was still less varied (Nur, 2012). Margunayasa states that 19 teachers $(44.2 \%)$ out of 43 elementary schools admit that they have never implemented a method/ model other than lecturing and discussion (Margunayasa, 2016). In general, teachers still rely on lecturing. Science instruction at elementary school focuses more on memorization, remembering and accumulating of various kinds of information. As the effect of such learning process, the fifth-grade students' science learning achievement in Singaraja city was low. The averages of the fifth-grade students science learning achievement in Cluster II, Cluster IX and Cluster XIII in Buleleng district in the odd semester of the school year 2016/2017 were 65.84; 68.41; and 66.98 respectively (Documentation Study Result, 2016). This is obviously contrary to the nature of science as knowledge and process (Sund \& Trowbridge, 1990). Science as knowledge is an accumulation of facts, concepts, laws, and theories about science, while science as process is an accumulation of scientific activities that are related to science.

A learning model which can accommodate the nature of science as knowledge and process is inquiry learning model. Inquiry learning is essential for well-educated and fundamental educational strategy for scientifically literate individuals (Kizilaslan at al, 2012). The type of inquiry learning that is suitable for elementary school students is guided inquiry learning since they do not have any experience in inquiry learning (Suastra, 2017). Guided inquiry stresses the importance of discovery process by the students themselves. Massialas states that guided inquiry learning can be defined as a teaching method that enables the students to move step by step from identification of a problem, hypothesis defining, problem formulation, data collection, result verification, and generalization to conclusion drawing (Massialas, 1991). In implementing the 2013 curriculum in Indonesia, the government expects that teachers can implement inquiry learning in the classroom. However, facts in the field are very different. A study by Margunayasa (2016) showed that 36 out $43(83.7 \%)$ homeroom teachers of the fifth grade in Singaraja city reported that they had never implemented guided inquiry model because: 1) they did not know guided inquiry learning model $(36.11 \%)$, and 2) they did not have time to implement it in the classroom $(63.89 \%)$ because they found it difficult to prepare the model. On the other hand, it is believed that guided inquiry learning has a very significant effect on the attainment of learning achievement.

Empirically, a study by Matthew \& Kenneth (2013) showed that students taught logic by using guided inquiry learning had better learning achievement than those who were taught by conventional teaching method. A research by Ergul at al (2011) also showed that the use of guided inquiry teaching method significantly improved science process skill and attitude in elementary school students. One of the strengths of guided inquiry learning model is that it provided the opportunity for the students to learn according to their cognitive style (Kurniasih \& Berlin, 2015). The students' characteristics, especially their cognitive style, can also influence their learning achievement (Zhang \& Sternberg, 2001). Hence, it is important that teachers accommodate students' cognitive learning achievement. 
The cognitive style has been defined as consistent individual differences in preferred ways of organizing and processing information and experience (Allinson \& Hayes, 1996). The cognitive style is a way an individual uses in processing, storing and using information to respond to a task or various kinds of situations in the environment. Cognitive style is a characteristic of personality that is relatively permanent, so that it can be used to explain an individual's behavior in facing various situations. Cognitive style is based on the time used to respond to a stimulus. Cognitive style can be grouped into two categories: reflective and impulsive (Gullo, 1988; Hayes \& Allinson, 1994; Kagan, 1966; Keller \& Ripoll, 2001; Pitassi \& Offenbach, 1978; Saracho, 1997). Subjects with a reflective cognitive style take more time to examine a problem, consider alternative solutions, and examine the accuracy and adequacy of a hypothesis. On the other hand, subjects with an impulsive cognitive style have the tendency to make a decision quickly and to respond to what comes into their mind rather than to do a critical examination. By knowing students' cognitive style, the teacher can present materials in a way that helps the students to understand them well. By considering the students' cognitive style, everything that they do can be understood by the teacher and the teacher can teach according to the students' ability. People will learn more effectively when the learning environment is compatible with their cognitive style (Hayes \& Allinson, 1994). Trout \& Crawley (1985) stated that one can cause an improvement in learning by matching cognitive styles and learning strategies. In addition, Bruininks (1970) also supported the statement that learners will learn more efficiently when they are presented information which is compatible with their cognitive style.

\section{Research Focus}

The aim of this study was: 1) to analyze the difference in science learning achievement between students who learned through guided inquiry learning model and those who learned through conventional learning model, and 2) to analyze the effect of interaction between teaching model and cognitive style on science learning achievement.

\section{METHOD}

\section{Design}

The quasi-experimental study that was carried out used a $2 \times 2$ factorial design (Dantes, 2012). The stages in this study were as follows: assessment of cognitive styles at the beginning of the experiment, followed by the implementation of guided inquiry in 12 meetings, and finally, a posttest was given to measure science learning achievement. The learning model used followed inquiry cycles from Liewelyin (2002) covering the stages of: (1) Inquisition - starting from the statement to be investigated, (2) Acquisition enabling a brainstorming procedure, (3) Supposition - identifying the statement to be tested, (4) Implementation - designing and carrying out a plan, (5) Summation collecting evidence and drawing conclusions, and (6) Exhibition - sharing and communicating results. However, up to the time of the present experiment the teaching of science in the fifth grade in Singaraja City had followed the conventional teaching (Margunayasa, 2016). 
The conventional teaching model in this study refers to the method used by elementary school science teachers in Singaraja City in teaching science and discussing topics which take the form of transfer of knowledge from teacher to the student. It usually starts with teacher brief explanation about the topic and continues with the students trying to answer some problems in the book and ends with presentation of the answers. The characteristic of the conventional teaching model are the tendency for lecturing to dominate, transfer of knowledge from teacher to the student, learning activities tend to be monotonous, one way communication, a lot of practice in solving problems and teacher centered teaching.

\section{Sample}

The population of this study consisted of fifth grade students from 43 elementary schools dispersed into 10 cluster (Cluster I, II, VI, VII, VIII, IX, X, XI, XII, and XIII). The sample used multi stage random sampling, done in 3 stages. At the first stage, 25\% was selected from 10 elementary school groups that were found in Singaraja city: elementary schools of Cluster II, Cluster IX, and Cluster XIII. Sampling at the second stage was done by taking at random $50 \%$ of elementary schools from three groups selected at the first stage. At the second stage 8 elementary schools were found as the sample. At the third stage from 8 elementary schools in the sample, 4 elementary schools (SDN) were selected as experiment group $(n=132)$ that consisted of SDN 1 Penarukan, SDN 4 Banyuning, SDN 1 Banjar Jawa and SDN 1 Baktiseraga and 4 elementary schools as control group $(n=107)$ which consisted of SDN 3 Penarukan, SDN 5 Penarukan, SDN 1 Astina and SDN 1 Banjar Tegal. The experimental group got a guided inquiry learning model treatment and the control groups got a conventional learning model, respectively.

\section{Instrument and Procedures}

To collect the data needed in this study, some instruments were used: science learning achievement test and The Matching Familiar Figures Test (MFFT). Science learning achievement test was made by the writer and was used to collect data on science learning achievement (reliability $=0.85$ ). The test consisted of 30 items in multiple choice type. MFFT was used to determine the tendency in students' cognitive style (reflective or impulsive) which became the moderator variables (reliability $=0.72$ ). MFFT test that was used in this study was adapted from MFFT developed by Warli (2010) based on the score and time used to answer the test, the subject can be categorized as impulsive or reflective. In this study the maximum time provided to answer 13 items in MFFT test was 15 minutes. The students were categorized as reflective if the time used by them $(t) \geq 7.5$ minutes and the items with correct answers $\geq$ 7 items. While students were categorized as impulsive if the time used by them $(t)<7.5$ minutes and the number of wrong answers $\geq 7$ items.

\section{Data Analysis}

In general the hypothesis testing in this study used two-way analysis of variance (ANOVA). The testing was done with the aid of SPSS 20.0. 


\section{FINDINGS}

The result of analysis of the mean score for science learning achievement for each group of data is presented on Table 1. Based on Table 1 it can be explained that: 1) the science learning achievement of the students who learned through guided inquiry learning model was higher than that of those who learned through conventional teaching model, 2) the science learning achievement of those who had reflective cognitive style was higher than that of those who had impulsive cognitive style, 3) the science learning achievement of those who learned through guided inquiry learning model was higher than that of those who learned through conventional teaching model in the students with reflective cognitive style, and 4) the science learning achievement of those who learned through guided inquiry learning model was lower than that of those who learned through conventional teaching model in the students with impulsive cognitive style.

Table 1

Mean Score in Science Learning Achievement for Each Groups

\begin{tabular}{|c|c|c|c|}
\hline $\begin{array}{l}\text { Teaching Model } \\
\text { Cognitive style }\end{array}$ & $\begin{array}{l}\text { Guided Inquiry } \\
\text { Learnig }\end{array}$ & $\begin{array}{l}\text { Conventional } \\
\text { Teaching }\end{array}$ & Total \\
\hline Reflective & 26.54 & 21.91 & 24.03 \\
\hline Impulsive & 21.66 & 22.83 & 22.23 \\
\hline Total & 23.93 & 22.35 & \\
\hline
\end{tabular}

Before testing the hypothesis, pre-requirement analysis testing was done through data normality test and variance homogeneity test. The data normality of each analysis unit was subjected to Kolmogorov Smirnov test which yielded the significant value $\mathrm{p}>0.05$. This means that the data on science learning achievement of all units of analysis had a normal distribution. The result of variance homogeneity through Levene test yielded the significant value $\mathrm{p}>0.05$. This indicates that the data on science learning achievement between teaching model groups and between cognitive style groups were homogenous. Then, hypothesis testing was done by using two-way ANOVA is presented on Table 2.

Table 2

Anova Result

\begin{tabular}{llllll}
\hline \multicolumn{1}{c}{ Source } & Type III Sum of Squares & df & Mean Square & F & Sig. \\
\hline Corrected Model & $446.094^{\mathrm{a}}$ & 3 & 148.698 & 21.657 & .000 \\
Intercept & 66131.375 & 1 & 66131.375 & 9631.3 & .000 \\
$\mathrm{~A}$ & 91.112 & 1 & 91.112 & 13.270 & .000 \\
$\mathrm{~B}$ & 119.783 & 1 & 119.783 & 17.445 & .000 \\
$\mathrm{~A} * \mathrm{~B}$ & 257.908 & 1 & 257.908 & 37.562 & .000 \\
Error & 817.077 & 119 & 6.866 & & \\
Total & 67022.000 & 123 & & & \\
Corrected Total & 1263.171 & 122 & & & \\
a. R Squared $=.353$ (Adjusted R Squared =.337) \\
\hline
\end{tabular}


The result of hypothesis testing showed that: (1) there is a significant difference in science learning achievement between the students who learned through guided inquiry learning model and those who learned through conventional teaching $(F=13.27$ and $\mathrm{p}<0.05)$, (2) there was a significant difference in science learning achievement between the students with reflective cognitive style and students with impulsive cognitive style ( $\mathrm{F}$ $=17.45$ and $\mathrm{p}<0.05)$, and $(3)$ there was a significant interaction effect between teaching model and cognitive style on science learning achievement $(F=37.56$ and $p<0.05)$. There was an interaction between teaching model and cognitive style in their effect on science learning achievement, as clearly shown in Figure 1. Because there was an interaction between the learning model and the cognitive style, then the analysis was continued through the t-test to test the simple effect. The result of simple effect t-test showed that: (1) there is a significant difference in science learning achievement between the students who learned through guided inquiry learning model and those who learned through conventional teaching model in those with reflective cognitive style $(\mathrm{t}=$ 10.55 and $\mathrm{p}<0.05$ ), and (2) there is no significant difference in science learning achievement between the students who learned through guided learning model and those who learned through conventional teaching model and those with impulsive cognitive style $(\mathrm{t}=0.33$ and $\mathrm{p}>0.74)$.

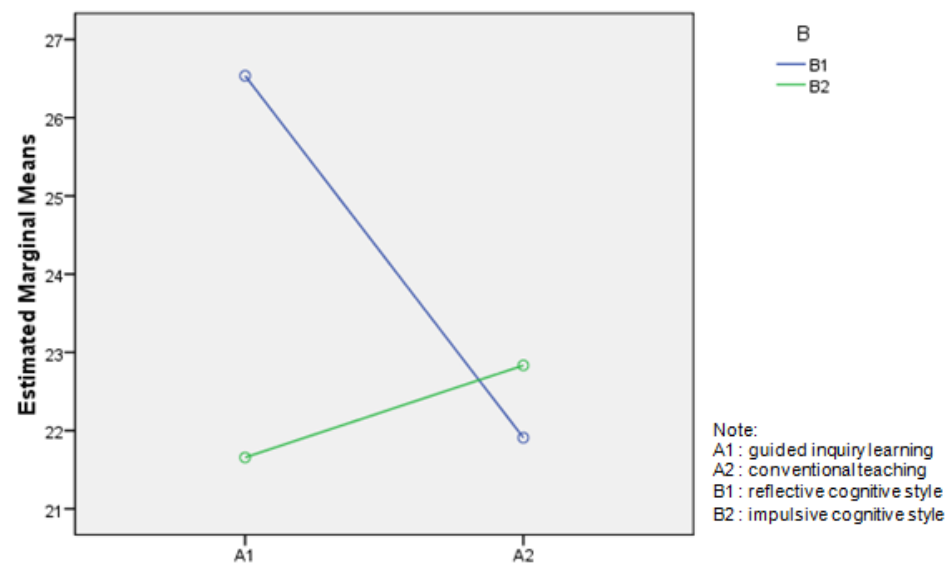

Figure 1

Interaction between teaching model and cognitive style on science achievement learning model

\section{DISCUSSION}

\section{The Effect of Guided Inquiry Learning On Science Learning Achievement}

Based on the result of data analysis it has been proven that there is a significant difference in science learning achievement between the students who learned through guided inquiry learning model and those who learned through conventional teaching model in the fifth grade students of elementary school in Singaraja city. Based on the stages of inquiry learning model, there are four stages which have direct relations with 
or effects on the attainment of science learning achievement. First, through Supposition Stage, the students are conditioned or trained to use their ability to predict, in which the prediction aspect is one of the C2 cognitive aspect of comprehending. Secondly, through Implementation Stage, the students are conditioned to be able to apply their understanding (part of the C3 cognitive aspect) to do the experimental activity. Third, Summation Stage, in which the students communicate the results they obtained to draw a conclusion. At this stage, the students are trained to be able to understand (C2) so that they can draw a conclusion from what they learned. Fourth, Exhibition Stage which enables the students to communicate the learning outcome to other people, both in writing and orally. At this stage, the other students also pay attention to what is presented by their peers who are doing the presentation and try to respond and evaluate the presentation. Hence, this stage obviously supports the attainment of the cognitive aspect of C5 or evaluating.

In general, science learning with guided inquiry learning model produces a good atmosphere for the development of student-active learning. Sund and Trowbridge stated that inquiry learning model provided the opportunity for student centered learning (Sund \& Trowbridge, 1990). Student active learning gives the opportunity to the students to become more engaged in learning. One psychological principle about learning states that the more the students are involved in the teaching and learning process, the more competent they will become in learning, and this will have an effect on their learning achievement. While conventional teaching which is often used by teachers does not give enough opportunities to the students to participate actively during the teaching and learning process, learning through discovery also supports the development of student active learning very much. Lee stated that inquiry-based teaching put a special emphasis on the core concept of cognitive learning and discovery learning, and its aim is to develop high order thinking. In other words, the teacher does not teach everything directly or explicitly (Lee, 2014). In inquiry learning, the teacher becomes the facilitator to help the students in exploring and developing their conceptual systems so that teaching becomes challenging.

Students' engagement in student-centered science learning is indicated in some science activities, for example, in the processes of observing, analyzing data, discussing, and presenting the result of observation. Guided inquiry learning model is an important model in science, since it involves various class activities such as asking questions, consulting reading books and other sources of information, analyzing data, and communicating results (Chen, 2011). The benefits of inquiry learning such as giving the students the opportunity to think, giving the students the opportunity to think carefully about ideas, problems and questions that are considered valid by the class, creating opportunities for the students to participate fully to increase their curiosity both inside and outside the class, making the students develop the spirit of personal initiative, cooperation, unity and group decision making ability, the skill and knowledge which make them explore their social environment (Opara \& Oguzor, 2011). Obviously, this can improve the ability to understand processes, concepts and relation among concepts.

International Journal of Instruction, January2019 • Vol.12, No.1 
The result of the study was supported by the result of the study by Matthew \& Kenneth (2013), which showed that students who were taught logic by using guided inquiry learning method obtained a better achievement than those who were taught logic by using conventional teaching method. The result of the study was also supported by Hilman (2014) that found that there was a positive and significant effect of guided inquiry learning with mind map on the students' science process skill and cognitive learning achievement. The result of the study was also supported by Artayasa that found that the effectiveness of these three levels of inquiry was significantly higher than that of the conventional strategy (Artayasa, Susilo, Lestari, \& Indriwati, 2017). In addition, the result of the study was also supported by the result of research done by Bilgin. Bilgin showed that the group of the students who used guide inquiry model had a better performance than those in the control group (Bilgin, 2009). Inquiry learning supported by argument maps had significantly affected the science process skills of prospective science teachers (Coban, 2013).

\section{The Effect of Interaction Between Guided Inquiry Learning and Cognitive Style on Science Learning Achievement}

Based on the result of statistical testing it was found that there was a significant interaction effect between teaching model and cognitive style on science learning achievement in the students of the fifth grades of elementary schools in Singaraja City. Then, the discussion was focused on the reflective and impulsive students in each lesson. The result of analysis showed that in the students who had reflective cognitive style, there was a significant difference in science learning achievement between those who learned through guided inquiry learning and those who learned through conventional teaching in the fifth grade students of elementary schools in Singaraja city. For the students with reflective cognitive style, the achievement of the students who learned science through guided inquiry learning model got a score 26.54 higher than that of those who learned through conventional teaching was 21.91 .

Ancilloti (1985) stated that reflective people tend to use analytical processing mode. In addition, Siegelman in Pitassi \& Offenbach (1978) stated that reflective people tend to have a longer span of attention, considering many solutions, thinking before responding. Reflective people have the characteristic of loving analog problems, of arguing more maturely and strategically in solving a problem. If it is related to science learning, guided inquiry learning favors the students with reflective cognitive style. Guided inquiry learning gives opportunities to the students in discovering concepts through scientific steps starting from problem identification, formulating hypotheses, doing an experiment, discussing the results, drawing a conclusion by themselves and communicating the result to other students. Through such steps the students are taught to be careful and are required to think of many solutions to a problem. Such learning is obviously preferred by students with reflective cognitive style.

In addition, through inquiry learning the students learn by maximally involving all their ability to find out and inquire systematically, critically, logically and analytically so that they can formulate their inquiry with more confidence. Hence, the reflective students who tend to think analytically can formulate by themselves their findings with 
confidence. Inquiry learning model has the advantage on increasing the students' intellectual potentiality (Dahar \& Liliasari, 1986). In addition, through inquiry learning the students are given the opportunities to seek and find out things that are related to observation. In addition, the students can learn how to do an inquiry. Learning through inquiry extends the students' memorizing process so that they have a higher learning achievement than the students who learn through conventional teaching.

While for the impulsive students the result of analysis showed that there was no significant difference in students' science learning achievement between those who had impulsive cognitive style who learned through guided inquiry learning and those who had impulsive cognitive style who learned through conventional teaching in the fifth grade students of elementary schools in Singaraja city. For the students with impulsive cognitive style, the science learning achievement of the students who learned through guided inquiry learning model was 21.66 , slightly lower than that of those who learned through conventional teaching was 22.83 .

There are two questions that need to be answered. First, why was the mean score in science learning achievement of the impulsive students higher in those who learned through conventional teaching than in those who learned through inquiry learning?; secondly, why was the difference in science learning achievement in the two groups insignificant? The answer to the first question is as follows. Impulsive students quickly respond to the situation but the response given is wrong. If it is related to science learning, conventional teaching favors the students with impulsive cognitive style, since the teaching is more teacher centered and is in the form of information transfer. The impulsive students feel more comfortable when given a complete explanation by the teacher. In addition, the conventional teaching is more competitive, in which the students are required to think accurately. The teacher asks questions and the students who raise their hands most quickly are asked to give answers to the questions given by the teacher.

The conventional teaching tends to encourage the students in a competition like a cock in a cock fighting, they work hard to defeat their classmates (Sulistiyorini, 2007). A competitive teaching encourages the students to give responses or answers to the teacher's questions quickly without thinking the best possible answer to the teacher's question. Hence, the impulsive students tend to give quick responses in learning so that they feel more comfortable in the conventional teaching. Unlike guided inquiry learning, which centers more on learning in the students through detailed scientific learning step by step. Material transfer from the teacher to the students is minimalized since through guided inquiry the students are trained to find their own concepts. Through guided inquiry the students are trained to find their own concepts. Through inquiry learning the students are trained to think analytically. The students who think analytically need more time in solving problems. The learning condition like this is obviously less appropriate for the students with impulsive cognitive style, who tend to be quick in giving solutions without being followed by analytical thinking. On the other hand, impulsive students tend to use holistic thinking pattern (Ancilloti, 1985). 
An answer to the question "why was the difference in science learning achievement insignificant between the students who learned through guided inquiry learning and those who learned through conventional teaching?" The answer is because there was a change in the tendency in the students' cognitive style from impulsive to reflective after the implementation of guided inquiry learning in 12 meetings. The implementation of guided inquiry learning gives priority to students' activity in discovering knowledge through analytical systematical scientific steps. Hence, without being aware of it, the impulsive students are conditioned through guided inquiry learning in a scientific learning environment and stresses some alternative solutions to problems, and the students are asked to make a conclusion from what they get though the experiment. Of course, the routine of learning with such a condition causes the students to be increasingly slower in giving responses and the responses given tend to be correct since they are acquired through scientific activities.

The explanation above is strengthened by the theory that states that students' impulsivity can decrease as they get older (Ault, Crawford, \& Jeffrey, 1972). Some scholars also state that cognitive style pattern can be modified as the effect of the demands of changing environment (Kozhevnikov, Carol, \& Stephen, 2014). The demands in guided inquiry learning makes the students modify their cognitive style tendency from impulsive to reflective. One of the proofs that there is a change in cognitive style from impulsive to reflective is the corrections in the students' worksheets. In the impulsive students' worksheets, in the prediction section, in the first to fifth meetings there is a tendency to contain corrections, but after entering the sixth to the twelfth meetings there number of corrections become less and less and even disappear. This indicates that the students became more careful in answering or they started to think before answering the questions after the implementation of guided inquiry learning. This is very different from the reflective students who tended to constantly answer from the first to last meeting without any corrections.

In addition to the stages of learning, there is a great probability that the assessment pattern or evaluation that is used also becomes the cause of the increase in the average in the students' learning achievement of the impulsive students. The assessment in guided inquiry learning is an active process throughout implemented through continuous assessment during the investigation process to express what has been learned by the students, to know whether the students need interventions, and what kind of intervention they need (Kuhlthau, 2010).

Some methods of assessment used are observation note, student performance, portfolio, product assessment, and rubric. In this study, the assessments used during the inquiry learning were observation sheet of the students' performance, portfolio, and report product assessment. Nitko (1996) states that portfolio assessment can be categorized as alternative, authentic or performance assessment.

The implementation of authentic assessment in the classroom in general is a strategical step aimed at increasing the quality of learning since the students can be expected to learn from the meaningful assessment (Marhaeni \& Artini, 2015). The meaning of meaningful here is that they have an understanding about what they have achieved and 
what they need to improve so that it can motivate them to continuously improve the language ability and skill. The implementation of authentic assessment through various techniques will be able to reveal, prove or show appropriately that the goal of learning and the competencies have truly been attained (Madjid, 2009). Hence, the implementation of authentic assessment in the classroom gives many contributions in improving the students' learning (Marhaeni at al., 2017).

Based on the explanation above, it can be known that the learning process and the assessment used in guided inquiry learning caused an improvement in the students' science learning mean score close to that of the impulsive students who learned through conventional teaching so that when tested statistically they did not show a significant difference. The result of this study agrees with Daraini (2012) that for the students with impulsive cognitive style, there is no difference in ability in problem solving between the students who learned through interactive multimedia-based learning and those who learned through linear multimedia learning.

Based on the explanation above the new finding in this study is that guided inquiry learning is more effective to be implemented for the students with the tendency to have reflective cognitive style compared with those with the tendency to have impulsive cognitive style. In addition, another finding in this study is that the tendency of the students with impulsive cognitive style to change to reflective cognitive style after the implementation of guided inquiry learning. Guided inquiry learning through the stage of asking questions, brainstorming of answers to the questions asked, formulating hypotheses to be tested, planning and collecting data, drawing a conclusion, and communicating the results obtained, the ability to change the students who previously had the characteristic of responding quickly to information without thinking of the probable solutions/ other alternatives to become those who have the characteristic of responding to the information slowly by thinking of the solutions / other alternatives to the problem solution deeply and analytically. Hence, the students' impulsivity is no longer stable and permanent, but can change according to the learning environment implemented.

\section{CONCLUSION}

Guided inquiry learning interacts with students' cognitive style in its effect on science learning achievement. Guided inquiry learning is implemented through a number of stages, starting from questions posed by the teacher. Then, brainstorming is performed concerning the questions given and a hypothesis is made to be tested or questions to be answered. After these activities, an experiment is designed and carried out, evidence is collected and conclusions are drawn. Finally, the results are communicated. Guided inquiry learning stages can be followed well by the students who have the tendency of reflective cognitive style. The students with a reflective cognitive style tend to spend more time to check problems, consider alternative solutions, and checking the accuracy and adequacy of the hypothesis so that the response/solution tends to be correct. They are different from the students with an impulsive cognitive style who tend to give responses quickly without checking the accuracy so that the solution given had a low level of correctness. Conventional teaching through lecturing which is teacher-centered 
and competitive for the students tends to favor students with an impulsive cognitive style.

Some suggestions can be made which include: to the teacher who teach elementary school science it is suggested to implement guided inquiry learning in teaching science at elementary school. The teacher should always identify the tendency in the cognitive style, that the students have before starting to teach. In this way the teacher can modify the method or model of teaching based on the student cognitive styles. In addition, to researchers it is suggested to do future research by implementing guided inquiry learning in other science topic by using a large sample, together with difference types of assessment, involving other psychological variable.

\section{ACKNOWLEDGEMENTS}

The writer would like to thank his promotion board: Prof. Dr. Nyoman Dantes, Prof. Dr. A.A.I.N. Marhaeni, MA and Prof. Dr. I Wayan Suastra,M.Pd. for their guidance and support. His thanks also goes to the rector of Ganesha University of Education, Dr. I Nyoman Jampel, M.Pd., the director of Postgraduate Study Program of Ganesha Universiy of Education, Prof. Dr. I Wayan Suastra, M.Pd., and the dean of the Faculty of Education, Prof. Dr. Ni Ketut Suarni M.S. for the support given during the course of completing his doctoral study.

\section{REFERENCES}

Allinson, C., \& Hayes, J. (1996). The cognitive style index: a measure of intuitionanalysis for organizational research. Journal of Management Studies, 33(1), 119-135.

Ancilloti, J.P. (1985). Dimension reflexive-impulsive de la personnalite et fonctionnement cognitif. Cabiers de Psychologie Cognitive, 5(6), 667-686.

Artayasa, I P., Susilo, H., Lestari, U. \& Indriwati, S.E. (2017). The effectiveness of the three levels of inquiry in improving teacher training students' science process skills. Journal of Baltic Science Education, 16(6), 908-918.

Ault, R.L., Crawford, D.E. \& Jeffrey, W.E. (1972). Visual scanning strategies of reflective, impulsive, fast-accurate, and slow-inaccurate children on the Matching Familiar Figures Test. Child Development, 43 (4), 1412-1417.

Bilgin, I. (2009). The effects of guided inquiry learning incorporating a cooperative learning approach on university students' achievement of acid and bases concepts and attitude toward guided inquiry learning. Scientific Research and Essay, 4(10), 10381046.

Bruininks, R. H. (1970). Teaching Word Recognition to Disadvantage Boys. Journal of Learning Disabilities, 3 (1), 28-37.

Chen, L. C. (2011). The Effects of integrated information literacy in science curriculum on first- grade students' memory and comprehension using the super3 model. Knowledge Management \& E-Learning: An International Journal, 3(3), 399-411.

Coban, G.U. (2013). The effects of inquiry supported by argument maps on science process skills and epistemological views of prospective science teachers. Journal of Baltic Science Education, 12(3), 271-288. 
Dahar, R. W. \& Liliasari. (1996). Interaksi Belajar Mengajar IPA. Jakarta: Universitas Terbuka.

Dantes, N. (2012). Metode Penelitian. Yogyakarta: Andi.

Daraini, R. (2012). Pengaruh pembelajaran berbasis multimedia dan gaya kognitif terhadap kemampuan pemecahan masalah matematika siswa SMP Negeri Lubuk Pakam. Jurnal Teknologi Pendidikan, 5(2), 236-243.

Ergul, R.; Simsekli, Y.; Calis, S.; Ozdilek, Z., Gocmencelebi, S. \& Sanli, M. (2011). The effects of inquiry-based science teaching on elementary school students' science process skills and science attitudes. Bulgarian Journal of Science and Education Policy, $5(1), 48-68$.

Gullo, D.F. (1988). An investigation of cognitive tempo and its effects on evaluating kindergarten children's academic and social competencies. Early Child Development and Care, 34(1), 201-215.

Hayes, J. \& Allinson, C. W. (1994). Cognitive style and its relevance for management practice. British Journal of Management, 5(1), 53-71.

Hayes, J. \& Allinson, C. W. (1998). Cognitive style and the theory and practice of individual and collective learning in organizations. Human Relations, 51(7), 847-871.

Hilman. (2014). Pengaruh pembelajaran inkuiri terbimbing dengan mind map terhadap keterampilan proses sains dan hasil belajar IPA. Jurnal Pendidikan Sains, 2(4), 221229.

Kagan, J. (1966). Reflection-impulsivity: the generality and dynamics of conceptual tempo. Journal of Abnormal Psychology, 71(1), 17-24.

Keller, J. \& Ripoll, H. (2001). Reflective-impulsive style and conceptual tempo in a gross motor task. Perceptual and Motor Skills, 92(3), 739-749.

Kizilaslan, A., Sozbilir, M. \& Yasar, M.D. (2012). Inquiry based teaching in Turkey: A content analysis of research reports. International Journal of Environmental \& Science Education, 7(4), 599-617.

Kozhevnikov, M.; Carol, E. \& Stephen, M. K. (2014). Cognitive style as environmentally sensitive individual differences in cognition: a modern synthesis and applications in education, business, and management. Psychological Science in the Public Interest, 15(1), 3-33.

Kuhlthau, C.C. (2010). Guided inquiry: school libraries in the $21^{\text {st }}$ century. School Libraries Worldwide, 16 (1), 1-12.

Kurniasih, I. \& Berlin, S. (2015). Ragam Pengembangan Model Pembelajaran untuk Peningkatan Profesionalitas Guru. Jakarta: Kata Pena.

Lee, H. Y. (2014). Inquiry-based teaching in second and foreign language pedagogy. Journal of Language Teaching and Research, 5(6), 1236-1244.

Liewellyn, D. (2002). Inquire within: Implementing inquiry based science standards. Thousand Oaks, CA: Corwin Press.

Madjid, A. (2009). Perencanaan Pembelajaran, Mengembangkan Standar Kompetensi 
Guru. Bandung: Remaja Rosdakarya.

Margunayasa, I. G. (2016). Pengaruh Model Pembelajaran Inkuiri Terbimbing, Gaya Kognitif, dan Motivasi Berprestasi Terhadap Keterampilan Proses Sains dan Hasil Belajar IPA pada Siswa Kelas V SD di Kota Singaraja (Studi Awal). Laporan Penelitian. Singaraja: Universitas Pendidikan Ganesha.

Marhaeni, A.A.I.N. \& Artini, L.P. (2015). Asesmen autentik dan pendidikan bermakna: implementasi kurikulum 2013. Jurnal Pendidikan Indonesia, 4(1), 499-511.

Marhaeni, A.A.I.N. (2017). Asesmen Autentik dalam Pembelajaran Bahasa Inggris. Jakarta: PT RajaGrafindo Persada.

Massialas, B. G. (1991). Discovery and inquiry methods. In A. Lewy (Ed). The international encyclopedia of curriculum. Oxford: Pergamon press PLC.

Matthew, B. M. \& Kenneth, I. O. (2013). A study on the effects of guided inquiry teaching method on students achievement in logic. International Researcher, 2(1), 133140.

Nitko, A.J. (1996). Educational Assessment of Students. New Jersey, Ohio: Meirril, an imprint of Prentice Hall.

Nur, F. M. (2012). Pemanfaatan sumber belajar dalam pembelajaran sains kelas V SD pada pokok bahasan makhluk hidup dan proses kehidupan. JESBIO, I (1), 14-20.

Opara, J. A. \& Oguzor, N. S. (2011). Inquiry learningal method and the school science currículum. Current Research Journal of Social Sciences, 3(3), 188-198.

Pitassi, T.D. \& Offenbach, S. I. (1978). Delay of reinforcement effects with reflective and impulsive children. The Journal of Genetic Psychology, 133(1), 3-8.

Saracho, O. N. (1997). Teacher'and Students' Cognitive Style in Early Childhood Education. London: Bergin \& Garvey.

Zhang, L. F. \& Sternberg, R. (2001). Thinking styles across cultures: their relationships with student learning. Perspectives on thinking, learning and cognitive styles, 197-226.

Suastra, I W. (2017). Pembelajaran Sains Terkini: Mendekatkan Siswa dengan Lingkungan Alamiah dan Sosial Budaya. Singaraja: Universitas Pendidikan Ganesha.

Sulistyorini, S. (2007). Model Pembelajaran IPA Sekolah Dasar dan Penerapannya dalam KTSP. Semarang: Tiara Wacana.

Sund, R.B \& Trowbridge, L. W. (1990). Teaching Science by Inquiry in The Secondary School. Ohio: Charles E. Merrill Publishing.

Susanto, A. (2013). Teori Belajar dan Pembelajaran di Sekolah Dasar. Jakarta: Kencana Prenada Media Group.

Trout, J.S. \& Crawley, F.E. (1985). The effect of matching intructional strategy with selected student characteristics on ninth grade physical science students' attitudes and achievements'. Journal of Research in Science Teaching, 22(5), 407-419.

Warli. (2010). Profil Kreativitas Siswa yang Bergaya Kognitif Reflektif dan Siswa yang Bergaya Kognitif Impulsif dalam Memecahkan Masalah Matematika. Disertasi. Surabaya: UNESA. 